\title{
Adolescentes, Controvérsias Sociocientíficas e Experiências Museais: a Mediação para Catalisar Diálogos sobre Ciência e Religião
}

\author{
Jessica Norberto Rocha ${ }^{(\mathbb{D})}$ - Luisa Massarani ${ }^{(\mathbb{D})}$ - Yurij Castelfranchi ${ }^{(\mathbb{D})}$ Juliane dos Santos Amorim
}

\begin{abstract}
Resumo
Neste estudo, de caráter qualitativo e exploratório, analisamos a visita de cinco grupos de adolescentes à exposição "Demasiado Humano" do museu Espaço do Conhecimento da Universidade Federal de Minas Gerais. A coleta de dados foi realizada durante as visitas dos grupos com registro de áudio e vídeo por meio de uma "câmera subjetiva" colocada na cabeça de uma pessoa por grupo. Foi utilizado um protocolo de pesquisa desenvolvido para compreender as experiências de adolescentes em museus de ciências. A partir de referenciais que abordam museus de ciências e controvérsias sociocientificas, comunicação pública da ciência e tecnologia e a percepção dos jovens brasileiros sobre ciência e religião, aprofundamos a análise qualitativamente. Observamos que os mediadores foram importantes para catalisar a emissão de opiniões, reflexões, conexões com o cotidiano e coconstrução de conhecimento. As interações estudadas mostram que é possível, embora desafiador, construir experiências museais com os adolescentes que articulem conceitos científicos, no contexto de controvérsias sociotécnicas. Mas, para que isso aconteça, os museus precisam planejar e pensar conteúdos, dinâmicas das visitas e mediação. Ficou clara a necessidade de um trabalho, por parte do museu, de aprofundamento, com os mediadores, da reflexão epistemológica sobre o funcionamento de uma controvérsia.
\end{abstract}

\section{Palavras-chave MUSEU DE CIÊNCIAS • VISITANTES • MEDIADORES • EDUCAÇÃO NÃO- FORMAL • CONTROVÉRSIAS SÓCIOCIENTÍFICAS}

\section{Teenagers, Socioscientific Controversies and Museum Experiences: Mediation to Facilitate Discussions about Science and Religion}

\begin{abstract}
In this qualitative and exploratory study, we analyzed the visit of five groups of teenagers to the exhibition "Demasiado Humano" at the museum Espaço do Conhecimento at the Federal University of Minas Gerais. During the, the data was collected through audio and video recording, using a "subjective camera" worn on the head of one participant from each group. A research protocol was developed and applied to understand the experiences of teenagers in science museums. We qualitatively deepened the analysis based on references that address science museums and socioscientific controversies, public communication of science and technology, and Brazilian youths' perceptions of science and religion. Our results indicate that conversations among teenagers and museum mediators were key elements of the visits. We observed that the mediators were essential to facilitate the exchange of opinions, reflections, connections with daily life, and knowledge co-construction. The studied interactions show that, although challenging, it is possible to create museum experiences with teenagers that articulate scientific concepts in the context of socio-technical controversies. However, museums need to plan accordingly and think about the content, dynamics and mediation of the visits. It became clear that the museum had to deepen the epistemological reflection on the functioning of a controversy with the mediators.
\end{abstract}

Keywords SCIENCE MUSEUMS • TEENAGERS • MEDIATORS • NON-FORMAL EDUCATION • SOCIOSCIENTIFIC CONTROVERSIES 


\section{Introdução}

Desinformação, polarização, conflitos políticos e morais atravessados por temas de cunho científico e tecnológico estão hoje entre os principais desafios não só para quem trabalha com educação em ciência e divulgação científica, mas para o próprio funcionamento da democracia. Tanto na discussão sobre políticas públicas, quanto no contexto acadêmico da pesquisa sobre apropriação social da ciência e tecnologia (C\&T) está emergindo com força a importância da construção de uma cidadania que seja também uma cidadania científica e tecnológica. Isso é, um conhecimento que possibilite aos cidadãos uma tomada de decisão informada, uma escolha responsável de quais informações utilizar e compartilhar para orientar suas decisões, que os empodere na participação social em controvérsias importantes sobre meio ambiente, saúde pública, novas tecnologias (Castelfranchi \& Fazio, 2021).

Neste processo de construção de uma cidadania científica - que não é só de alfabetização (científica, em saúde, informacional, tecnológica), mas sobretudo de apropriação social e participação social em C\&T - para além da educação formal, é importante reconhecer a contribuição da educação não formal, sendo os museus de ciências instituições importantes atuando na relação ciência-sociedade (Miller, 2013). Nessa perspectiva, Bandelli (2014) argumenta que eles têm sido considerados organizações-chave e plataformas para a cidadania científica. Se, anteriormente, os museus eram mais orientados à produção, conservação e valorização do conhecimento científico e de suas coleções, atualmente, espera-se que eles também atuem em contextos científicos, socioculturais e políticos, assumindo papel fundamental no engajamento dos diversos tipos de públicos em questões tecnocientíficas (Marandino et al., 2020).

Nesse sentido, as estratégias de comunicação dos museus de ciências "para" e "com" o público também vêm se modificando. Os públicos têm mais oportunidades para compartilhar experiências e conhecimentos e para fazer conexões significativas entre a temática abordada na exposição e suas próprias vidas. Sob ponto de vista semelhante, Schiele (2008) argumenta que os visitantes desejam ser ouvidos, querem ser atores e exercitar seu direito de voz. Essa afirmação também está em consonância com as ideias de Einsiedel e Einsiedel (2004, p. 73), que sinalizam que há um movimento dos museus se transformarem em "Ágoras modernas" (em suas palavras: "um caldeirão de debate público") para cidadãos e, por isso, são necessárias transformações no processo comunicativo das instituições museológicas.

Para Durant (2004), os profissionais de museus e seus tomadores de decisões não podem mais assumir que possuem todas as respostas e destaca que é importante apresentar nas exposições as incertezas, as dúvidas os questionamentos da ciência, inerentes à própria construção do conhecimento científico. Segundo o pesquisador, nessa configuração, a base da relação museu-visitante deve ser o diálogo. Nessa mesma perspectiva, Marandino et al. (2016) acreditam que exposições sobre temáticas sociocientíficas, particularmente as controversas, tendem a convidar os visitantes a formular e defender pontos de vista. Diante desse contexto, nos tópicos a seguir trazemos referenciais teóricos que respaldam este estudo, abordando museus de ciências e controvérsias sociocientificas e a percepção dos jovens brasileiros sobre ciência e religião. 


\section{Museus de ciências e controvérsias sociocientíficas}

As exposições museais podem envolver controvérsias científicas, temas ou fenômenos em relação aos quais não existe consenso na comunidade acadêmica. Mas frequentemente, uma exposição pode tocar, propositalmente ou não, controvérsias sociocientíficas. São temas presentes na esfera pública, atravessados não apenas por questões internas ao campo científico, mas que possuem também implicações políticas, ou que despertam embates de valores ou entre diferentes sistemas de crenças. Definimos neste texto as controvérsias sociocientíficas, ou sociotécnicas, como aquelas em que, para além da dimensão técnica e científica, existe uma diferença de opinião entre pessoas ou grupos interessados no assunto, tais como pesquisadores, empresas, instituições públicas, movimentos sociais (Diaz Moreno \& Jiménez-Liso, 2011). Uma controvérsia sociocientífica não é necessariamente uma controvérsia científica, mas uma situação em que aquilo que para alguns é fato, dado objetivo, para outros é "feito": um artefato (Latour, 2002). Quando atores diferentes atribuem objetividade a "fatos" diferentes, e quando tais atores não podem mais se ignorar, isto é, quando a discordância não pode ser invisibilizada, temos uma controvérsia sociotécnica (Venturini, 2010). Neste sentido, por exemplo, a crise climática envolve tanto controvérsias científicas (sobre como, atuar com mais eficiência para uma mitigação do impacto global das mudanças climáticas), como controvérsias sociotécnicas (pelo fato de existirem grupos de interesse consistentes, e com boa visibilidade midiática, que rejeitam parte das evidências científica, ou rejeitam as diretrizes políticas formuladas por especialistas).

Tais situações de controvérsias são extremamente importantes para os museus contemporâneos, porque implicam que temas que o museu trata como meramente científicos, internos ao campo da pesquisa, possam gerar nos visitantes reações em termos de crenças, sistemas de valores e considerações morais (Hodson, 2013) ou reflexões sobre como a ciência afeta decisões que tomamos em nosso cotidiano (Brotman et al.,, 2010). Mas não é esta a razão principal da importância de se pensar o papel das controvérsias sociotécnicas e sociocientíficas nos museus: há evidências marcantes, no campo da comunicação pública da ciência, que, em caso de temas controversos, o que mais afeta as atitudes das pessoas, e sua aceitação ou rejeição da ciência, não é a falta de informação, mas a falta de confiança. Museus que invisibilizam ou negam a existência de controvérsias sociocientíficas são museus que têm maiores chance de fracassar tanto em seu projeto de diálogo com o público, quando em seus objetivos educativos e de divulgação científica (Castelfranchi \& Fazio, 2021).

Assim, para Contier e Marandino (2020) temas científicos que aparecem em exposições possuem potencial para ser abordados ou mesmo interpretados de forma controversa pelo público, mesmo quando o objetivo da exposição não é tratá-los nessa perspectiva:

mesmo que uma exposição não opte por uma abordagem controversa, trazendo as diferentes visões de variados atores sobre o tema e os argumentos contrários e favoráveis a ele, isso não significa que os visitantes não possam discordar, 
concordar, levantar outros pontos de vista, debater com outros visitantes e, até mesmo, tomar posições contrárias, apaixonadas e radicalmente opostas àquelas apresentadas pelos museus (Contier \& Marandino, 2020, p. 34).

No Brasil, alguns museus de ciências têm incluído em suas exposições controvérsias sociocientíficas ou sociotécnicas, buscando um entrelaçamento entre assuntos internos ao campo da ciência com temáticas mais amplas da cultura e da sociedade. Contudo, essas práticas ainda são escassas e muitas vezes temporárias, como explicam Contier (2018) e Contier e Marandino (2020): a maioria dos museus de ciências constrói suas exposições focando principalmente, tanto no acervo, como na dinâmica da experiência museal, no processo de recepção por parte do público de noções e teorias científicas. Para Marandino et al. (2020), não é tarefa simples desenvolver propostas que abordem as relações entre a ciência e a sociedade e que discutam temas que são controversos. Por essa razão, ainda prevalece nos museus de ciências um modelo de comunicação centrado na apresentação de conteúdos e fenômenos científicos, que tem como pressuposto um déficit de conhecimento por parte do público e um modelo em que, de forma predominante, o conhecimento seria, no museu, transferido de forma unidirecional, da exposição para o público (Contier, 2009; 2018). Essa constatação também está de acordo com os estudos estrangeiros de Delicado (2009) e Pedretti (2002) que argumentam que ainda predominam as exposições que exibem a ciência de forma a não evidenciar os conflitos e potenciais controvérsias e como uma coleção de fatos incontestáveis.

Além dos visitantes e da exposição em si, temos um ator - o mediador. Esse profissional assume diversas tarefas nos museus brasileiros: além de mediar a exposição, desenvolve ações educativas, oferece oficinas e cursos etc. Cada museu adota a sua própria forma de trabalho: alguns museus se organizam para que os mediadores realizem visitas guiadas com todos ou a maioria dos visitantes, outros posicionam os mediadores em locais estratégicos ou exposições específicas para serem abordados pelos visitantes, e outros fornecem os mediadores apenas para visitas agendadas e atividades especiais (Marandino, 2008; Norberto Rocha, \& Marandino, 2020; Lima, \& Rocha, 2021).

$\mathrm{O}$ mediador ao dialogar com os visitantes pode contribuir para a diversidade de opiniões e informações sobre temas propostos pela instituição (Contier, 2018). Diversos pesquisadores indicam seu papel de catalisar discussões e a complexidade que sua ação pode alcançar (Contier, 2018; Marandino, 2008; Lima, \& Rocha, 2021). Para Rodari e Merzagora (2007, p. 10), eles são "o único 'artifício museológico' realmente bidirecional e interativo". Massarani et al. (2019b), por sua vez, encontraram evidências de que a interação entre adolescentes e mediadores pode culminar em um diálogo frutífero e rico, já que o profissional pode complexificar os temas trazendo para a pauta termos científicos, hipóteses e explicações, relacionando-os a conhecimentos anteriores dos visitantes. 


\section{Percepção dos jovens brasileiros sobre ciência e religião}

A origem da vida, o uso de vacinas, o uso de contraceptivos, doação de órgãos, aborto e outros temas são perpassados por argumentos que envolvem ciência e religião. Não é nova essa relação de controvérsia, demonstrada pela própria história da ciência "o desenvolvimento da ciência ocidental moderna esteve em profundo entrelaçamento com a religião" (Mota, 2013, p. 98).

O que pode parecer novo, entretanto, é a posição dos jovens do século XXI com essa relação. Mota (2013), em pesquisa realizada com 2.365 estudantes do Ensino Médio de 84 escolas, em amostragem estratificada e de representatividade nacional, obteve resultados que chamou de "surpreendentes". A pesquisa, que visou mapear a atitude de aceitação/rejeição da teoria da evolução biológica desses estudantes e identificar possíveis influências das crenças pessoais religiosas nessa aceitação, revelou alto índice de atitude positiva dos estudantes em relação à religiosidade ativa, isto é, demonstrando que a religião é valorizada pelos jovens, afirmando serem pessoas religiosas e de fé e terem compreensão e crença nas doutrinas religiosas. O surpreendente para a pesquisadora foi o dado de que a religiosidade não impediu de acreditar na evolução biológica. Para ela, "a aceitação da evolução biológica por parte dos estudantes sem que, para tanto, tenham de abrir mão de suas crenças religiosas, indica uma visão de mundo que é compatível com a ciência" (Mota, 2013, p. 217).

Para Oliveira et al., (2017), que estudaram a opinião de jovens brasileiros e italianos sobre evolução humana e religião, a educação formal é um meio que contribui com o ensino de temas científicos e representa uma visão de mundo científica. Entretanto, a sociedade, os ambientes de educação não formal e a socialização contribuem para a "construção de visão de mundo pelo indivíduo, a partir de um processo constante de análise de si próprio à luz do meio ambiente" (Oliveira et al., 2017, p. 136) e que resultam em diferenças nas visões de mundo por cada um dos jovens.

$\mathrm{Na}$ pesquisa "O que os jovens brasileiros pensam da ciência e da tecnologia" (Massarani et al, 2021a) - em que se utilizou a metodologia de survey e foram ouvidas 2.206 pessoas com idade entre 15 e 24 anos, residentes em todas as regiões do Brasil, em amostra probabilística - , os dados revelam que a maioria dos jovens manifestam grande interesse pelos temas "religião" (67\%) e "ciência e tecnologia" (67\%), abaixo apenas de "Meio ambiente" (80\%) e "Medicina e saúde" (74\%) e acima de Esportes (62\%); Arte e cultura (58\%) e Política (30\%).

Mediante o exposto, buscamos compreender como se deu a relação entre adolescentes e mediadores na abordagem de questões potencialmente controversas ciência e religião - na exposição "Demasiado Humano" do Espaço do Conhecimento (EC), um dos espaços culturais e museus de ciências da Universidade Federal de Minas Gerais (UFMG). Somado a isso, exploramos como a exposição foi vivenciada pelos grupos de adolescentes, com foco em como eles lidam com essas questões e como os mediadores podem (ou não) catalisar uma comunicação que oportunize espaços para emissão de opiniões, trocas, reflexão e coconstrução de conhecimentos. O texto 
está organizando em outras três seções, com suas respectivas subseções. Na primeira, apresentamos a metodologia de coleta e análise dos dados. Na segunda, descrevemos brevemente a exposição analisada no Espaço do Conhecimento. A seguir, discutimos de forma sucinta algumas evidências sobre a opinião dos jovens brasileiros sobre C\&T e a relação com a religião. Por fim, analisamos os dados coletados e formulamos algumas conclusões da pesquisa.

\section{Metodologia}

Este estudo se insere no escopo do Instituto Nacional de Comunicação Pública da Ciência e Tecnologia (INCT-CPCT), com apoio do Conselho Nacional de Desenvolvimento Científico e Tecnológico (CNPq) e da Fundação de Amparo à Pesquisa do Estado do Rio de Janeiro (Faperj) e da Red de Museos y Centros de Ciencia (Musa- Iberoamericana) com apoio do Cyted - Programa Iberoamericano de Ciencia y Tecnología para el Desarollo. É parte de uma pesquisa maior chamada "Olhar do Visitante" que tem sido desenvolvida em diversos museus da região da Iberoamérica e tem como objetivo desenvolver estratégias e ferramentas para compreender a experiência museal dos visitantes, em particular adolescentes em grupos de amigos, fora do contexto de visita escolar (cf. Massarani et al., 2019a; Massarani et al., 2019b; Massarani et al., 2019c; Massarani et al., 2020; Norberto Rocha et al., 2021a, Norberto Rocha et al., 2021b; Massarani et al., 2021b; Norberto Rocha et al., no prelo).

A presente investigação está estruturada no referencial metodológico de pesquisa exploratória e qualitativa - muito utilizada para estudos em educação em museus, educação não formal e divulgação da ciência, como indicam Marandino et al. (2009) e Norberto Rocha (2018).

\section{Universo de estudo: “Demasiado Humano”, uma exposição do Espaço do Conhecimento da UFMG}

Um exemplo de exposição de longa duração que traz diferentes pontos de vista sobre origem da vida e pode ser potencialmente controversa, dado que essa temática conecta e coloca em interação saberes, crenças, religião, e ciência, é a "Demasiado Humano" do Espaço do Conhecimento. Inaugurado em 2010, o espaço, localizado na Praça da Liberdade em Belo Horizonte, Minas Gerais, é considerado como um museu de ciências que conjuga cultura, ciência e arte.

A exposição "Demasiado Humano" é composta por painéis, fotos, ilustrações, dioramas e cenários e, em menor quantidade, aparatos multimídia interativos e réplicas de animais e de fósseis. Para a curadoria do museu, a exposição tem como princípio a narrativa sobre a busca do conhecimento, "tem como temas a origem do universo, o surgimento da espécie humana e o povoamento da Terra, as cosmogonias" e "pretende apontar os modos como nossa civilização vê e constrói o mundo, numa miríade de formas" (Leite, 2010, p. 15). Essa exposição, em especial, possui potencial para ser tratada partir de uma abordagem sobre controvérsias sociocientífica. Trata-se de um 
potencial, pois a exposição em si - em seu conteúdo textual e expográfico - não aborda controvérsias, mas se limita a apresentar diferentes mitos de origem, enquanto outras seções do museu apresentam ao público fatos sobre a origem do Universo ou a evolução biológica. Contudo, controvérsias costumam emergir frequentemente na experiência museal, especialmente a partir de questionamentos e demanda do público, e podem ser aproveitadas pelos mediadores como recurso para discussão e estímulo para aprofundamento dos temas. Um dos ambientes com tal potencial é o Cosmogonias: uma sala que contém seis dioramas que representam as cosmogonias grega, judaicocristã, maia-quiché, iorubá e maxacali e um relativo à cosmologia. Para a curadora, esse módulo apresenta inúmeras formas de narrativas sobre a passagem do homem pela Terra, pois "as civilizações seguem seus mitos, porque estes guardam os mistérios da existência; e o conhecimento jamais revelado é a quimera que impulsiona a infinita criação" (Leite, 2010, p. 54). O outro módulo expositivo é o Origens e Extratos do tempo, que, por meio de painéis, apresenta conhecimentos e discussões de alguns ramos da ciência contemporânea, na tentativa de dialogar a respeito das origens do universo e da vida.

\section{A coleta de dados e os sujeitos de pesquisa}

Cinco grupos de adolescentes (com idade entre 13 e 17 anos), amigos entre eles, estudantes de escolas públicas, foram convidados para visitar o Espaço do Conhecimento da UFMG. Para selecionar os sujeitos de pesquisa utilizamos uma amostra não probabilística que usa cadeias de referência chamada "amostragem por bola de neve" (do inglês snowball sampling), muito usada em pesquisa social de caráter qualitativo e útil quando a pesquisa envolve questões pessoais dos participantes da pesquisa (Biernarcki, \& Waldorf, 1981; Bernard, 2005).

As sementes, ou pontos iniciais da bola de neve, foram pessoas conhecidas dos autores deste artigo que indicaram outros adultos que tinham filhos ou eram professores de adolescentes com o perfil desejado. Cada grupo participante foi oriundo de uma indicação diferente, buscando, assim, diversidade no público estudado. Após o contato com o adulto responsável por um adolescente, fizemos o convite ao adolescente e solicitamos que ele convidasse outros três ou dois amigos estudantes de escolas públicas para a visita ao museu. A participação somente dos adolescentes na visita, após explicação detalhada dos procedimentos, foi autorizada pelos pais ou responsáveis de cada um deles nos termos de consentimento. Os adolescentes também assinaram um documento de anuência da sua participação voluntária.

No detalhamento dos dados serão usadas as letras " $G$ " para se referir ao grupo e "V" a visitante. Os visitantes são numerados em cada grupo, sendo o V1 o adolescente que usou a câmera. Na transcrição também utilizamos "M" e "Ma" para mediador e mediadora, respectivamente. 
Figura 1. Perfil dos adolescentes

\begin{tabular}{|c|c|c|c|c|c|}
\hline Grupo & Adolescente & Ano escolar & $\begin{array}{l}\text { Idade- } \\
\text { Gênero }\end{array}$ & Cidade/Estado & $\begin{array}{l}\text { Tempo de } \\
\text { visita }\end{array}$ \\
\hline \multirow{4}{*}{ G1 } & V1 & $1^{\circ}$ ano E. M. & $16-\mathrm{F}$ & Belo Horizonte/MG & \multirow{4}{*}{$39 \min 22 \mathrm{~s}$} \\
\hline & $\mathrm{V} 2$ & $1^{\circ}$ ano E. M. & $15-\mathrm{F}$ & Belo Horizonte/MG & \\
\hline & V3 & $2^{\circ}$ ano E. M. & $17-\mathrm{M}$ & Belo Horizonte/MG & \\
\hline & V4 & $2^{\circ}$ ano E. M. & $16-\mathrm{M}$ & Belo Horizonte/MG & \\
\hline \multirow{4}{*}{ G2 } & $\mathrm{V} 1$ & $1^{\circ}$ ano E. M. & $15-\mathrm{F}$ & Santa Luzia/MG & \multirow{4}{*}{$36 \min 17 \mathrm{~s}$} \\
\hline & $\mathrm{V} 2$ & $1^{\circ}$ ano E. M. & $14-\mathrm{F}$ & Belo Horizonte/MG & \\
\hline & V3 & $1^{\circ}$ ano E. M. & $16-\mathrm{M}$ & Belo Horizonte/MG & \\
\hline & V4 & $1^{\circ}$ ano E. M. & $16-\mathrm{M}$ & Ibirité/MG & \\
\hline \multirow{3}{*}{ G3 } & V1 & $9^{\circ}$ ano E. F. & 14-M & Belo Horizonte/MG & \multirow{3}{*}{$45 \min 50 \mathrm{~s}$} \\
\hline & $\mathrm{V} 2$ & $9^{\circ}$ ano E. F. & $14-\mathrm{F}$ & Belo Horizonte/MG & \\
\hline & V3 & $9^{\circ}$ ano E. F. & $14-\mathrm{F}$ & Belo Horizonte/MG & \\
\hline \multirow{3}{*}{ G4 } & $\mathrm{V} 1$ & $1^{\circ}$ ano E. M. & $14-\mathrm{M}$ & Belo Horizonte/MG & \multirow{3}{*}{$51 \mathrm{~min}$} \\
\hline & $\mathrm{V} 2$ & $9^{\circ}$ ano E. F. & $14-\mathrm{F}$ & Belo Horizonte/MG & \\
\hline & V3 & $2^{\circ}$ ano E. M. & $15-\mathrm{F}$ & Belo Horizonte/MG & \\
\hline \multirow{3}{*}{ G5 } & V1 & $3^{\circ}$ ano E. M. & $17-\mathrm{F}$ & Belo Horizonte/MG & \multirow{3}{*}{$52 \min 29 s$} \\
\hline & $\mathrm{V} 2$ & $1^{\circ}$ ano E. M. & $15-\mathrm{F}$ & Belo Horizonte/MG & \\
\hline & V3 & $3^{\circ}$ ano E. M. & $16-\mathrm{F}$ & Belo Horizonte/MG & \\
\hline & & & & Total de gravação: & $3 \mathrm{~h} 44 \mathrm{~min} 58 \mathrm{~s}$ \\
\hline
\end{tabular}

Fonte: autoria própria

Como está detalhado na Figura 1, obtivemos 17 sujeitos de pesquisa (11 meninas e seis meninos), sendo dois grupos (G1 e G2) com quatro participantes e três grupos (G3, G4 e G5) com três participantes cada. A maioria era residente na capital Belo Horizonte, em bairros de classe média e classe média baixa, e apenas dois residentes em cidades da região metropolitana, Ibirité e Santa Luzia.

As visitas, em contexto não escolar e guiadas por mediadores do Espaço do Conhecimento (conforme acontecia tradicionalmente no museu), foram realizadas em dias úteis nos meses de novembro e dezembro de 2017 e janeiro e fevereiro de 2018 . Pedimos que o primeiro grupo escolhesse uma exposição para visitar primeiro. A escolha foi a exposição "Demasiado Humano". Assim, para fins de unidade e comparabilidade dos dados essa opção do primeiro grupo determinou a coleta de dados com os outros quatro grupos. Isso significa que todos os grupos visitaram, para fins deste estudo, a exposição "Demasiado Humano", mas que puderam, posteriormente e no mesmo dia, visitar outras exposições do museu e participar da sessão de planetário, mas sem estarem participando da pesquisa.

A coleta de dados foi realizada com o mesmo protocolo adotado pela pesquisa maior "Olhar do visitante" (cf. Massarani et al., 2019a; Massarani et al., 2019b; Massarani et al., 2019c; Massarani et al., 2020; Norberto Rocha et al., 2021a, Norberto Rocha et al., 2021b; Massarani et al., 2021b; Norberto Rocha et al., no prelo). A gravação das 
visitas é realizada por meio de uma "câmera subjetiva" (do tipo GoPro) posicionada na cabeça de um dos visitantes de cada grupo de adolescentes, para captar a imagens e sons a partir do ponto de vista do indivíduo. Esse método - também chamado como "point-of-view camera" - vem sendo utilizado em diversos estudos na área de ciências sociais (cf. Lahlou, 2011; Glăveanu \& Lahlou, 2012; Sumartojo \& Pink, 2017) e permite uma visualização contextualizada do ambiente e do indivíduo que participa da pesquisa, trazendo riqueza de informações verbais e não verbais e elementos que possam explicitar atitudes, comportamentos, falas e outras ações que acontecem em um museu de ciências.

\section{Codificação dos vídeos}

Todo o material audiovisual foi codificado no software Dedoose 8.0.23, que permite a identificação, categorização e marcação de trechos em que ocorrem as interações dos visitantes (ações corporais, textuais e atitudinais) de forma simultânea. O protocolo de codificação dos vídeos foi, inicialmente, construído a partir de uma adaptação do proposto pelo grupo de pesquisa canadense GREM (Groupe de recherche sur léducation et les musées), que reelabora para o contexto dos museus o modelo sistêmico do triângulo pedagógico, proposto por Legendre (1983) (Allard et al., 1998). Esse modelo é útil para analisar a forma como as experiências são organizadas em um museu, já que identifica as relações entre três atores fundamentais nesse espaço - os artefatos (módulos expositivos), os atores do museu (mediadores) e os visitantes e suas relações - e tem sido usado em vários estudos no contexto museal (Soto Lombana et al., 2009; Soto Lombana et al., 2013). Essa interpretação da dimensão educativa dos museus proposta pelo GREM foi útil neste estudo para estabelecer categorias gerais de identificação das experiências das visitas, sendo, portanto, uma ferramenta de categorização inicial e geral das experiências museais dos visitantes, constituindo os eixos principais do protocolo.

Tendo como ponto de partida esse modelo, foram associadas a esse protocolo a construção de categorias e subcategorias por pesquisadoras, brasileiras e estrangeiras, envolvidas no estudo que envolveu adolescentes com a mesma faixa etárias em oito museus de ciências da América Latina (dois de cada país: Argentina, Colômbia, México e Brasil, sendo o EC/UFMG um deles) (cf. Massarani et al., 2019a; Massarani et al., 2019b; Massarani et al., 2019c; Massarani et al., 2020; Norberto Rocha et al., 2021, no prelo). Essas subcategorias foram criadas para qualificar a experiência dos adolescentes nos museus utilizando uma perspectiva top-down (dedutivamente construído a partir da literatura e das perguntas iniciais de pesquisa) e bottom-up (criando códigos específicos a partir de temas, expressões, questões que emergiram a partir do próprio material empírico, após uma primeira imersão e análise descritiva do material coletado).

Assim, a codificação foi iniciada com um protocolo de análise com categorias que foram discutidas e revistas na fase inicial do processo de interpretação dos vídeos coletados em um museu dos oito museus, de modo a integrar novos elementos trazidos pela empiria. Os vídeos desse museu foram codificados às cegas pelas seis pesquisadoras 
com vistas a validação e revisão das categorias e subcategorias. Na maioria dos dados coletados houve consenso das pesquisadoras. Nos poucos casos em que houve divergência, os dados eram trazidos para a coletividade das seis pesquisadoras, as opiniões debatidas, as descrições das subcategorias aprimoradas quando necessário e prevalecia a codificação de adesão da maioria. Depois desse processo, os vídeos coletados com os cinco grupos de adolescentes no EC foram analisados e codificados na íntegra por uma dupla oriunda dessas mesmas seis pesquisadoras-codificadoras. $\mathrm{O}$ protocolo produzido é, então, dividido em cinco dimensões (Conversações, Tipos de Interação, Fotos, Mudança e Emoção) e suas respectivas categorias (cf. Massarani et al., 2019a; Massarani et al., 2019b; Massarani et al., 2019c; Massarani et al., 2020).

Neste estudo nos aprofundamos nas categorias de maior ocorrência nos vídeos coletado no Espaço do Conhecimento e que permitiram focar no nosso objetivo de pesquisa. Assim, discutiremos os resultados referentes às dimensões mais expressivas que emergiram da codificação da totalidade de material audiovisual coletado: Tipos de Interação e Conversações.

Figura 2. Categorias Tipos de Interação e Conversações

\begin{tabular}{|l|l|}
\hline \multicolumn{2}{|c|}{ TIPOS DE INTERAÇÃO } \\
\hline Visitante-visitante & $\begin{array}{l}\text { Quando os visitantes interagem e conversam entre si, } \\
\text { independentemente, do conteúdo dessa conversa. }\end{array}$ \\
\hline Visitante-mediator & $\begin{array}{l}\text { Quando os visitantes escutam as orientações e informações } \\
\text { do mediador ou conversam com ele, independentemente, do } \\
\text { conteúdo dessa conversa, podendo ser, sobre temáticas da } \\
\text { exposição e temas que tangenciam, orientações sobre a visita e } \\
\text { experiência museal ou não. }\end{array}$ \\
\hline Visitante-módulo expositivo & $\begin{array}{l}\text { Quando os visitantes interagem com o módulo expositivo, } \\
\text { podendo ser: atividade interativa; interação contemplativa; } \\
\text { Leitura }\end{array}$ \\
\hline Atividade interativa & $\begin{array}{l}\text { A interação se dá pela: imersão; experimentação; interação } \\
\text { física (apertar botões, girar manivelas etc.) necessárias para a } \\
\text { continuidade da narrativa/ enredo/conteúdo do módulo; controle } \\
\text { de variáveis e interferência no resultado final/produto do módulo; } \\
\text { e/ou jogo. }\end{array}$ \\
\hline Interação contemplativa & $\begin{array}{l}\text { Contemplação, observação, visualização sem toque/ manipulação } \\
\text { de um módulo expositivo ou parte dele específico. }\end{array}$ \\
\hline $\begin{array}{l}\text { Leitura de painel/texto/foto } \\
\text { explicativo }\end{array}$ & $\begin{array}{l}\text { A interação se dá pela leitura em voz alta de textos (integrais ou } \\
\text { parte) de placas informativas, painel, legenda, texto, charge, dos } \\
\text { módulos expositivos. }\end{array}$ \\
\hline
\end{tabular}

Fonte: Adaptado de Massarani et al., 2019a; Massarani et al., 2019b; Massarani et al., 2019c; Massarani et al, 2020. 
Figura 2. Categorias Tipos de Interação e Conversações (continuação)

\begin{tabular}{|c|c|}
\hline \multicolumn{2}{|r|}{ CONVERSAÇÕES } \\
\hline \multicolumn{2}{|r|}{ Conteúdo das conversações } \\
\hline $\begin{array}{l}\text { Conversas sobre temas de } \\
\text { ciências }\end{array}$ & $\begin{array}{l}\text { Diálogos sobre algum tema científico, discutem dilemas éticos e } \\
\text { morais da ciência, impacto social da atividade científica, trazem } \\
\text { dados ou conteúdos científicos etc. }\end{array}$ \\
\hline $\begin{array}{l}\text { Conversas sobre a exposição e } \\
\text { temática não científica }\end{array}$ & $\begin{array}{l}\text { Diálogos sobre temáticas que são abordadas pela exposição mas } \\
\text { que não se referem a temas de ciência previstos na categoria } \\
\text { acima. }\end{array}$ \\
\hline $\begin{array}{l}\text { Conversas sobre exposição } \\
\text { (funcionamento, design, } \\
\text { experiência museal) }\end{array}$ & $\begin{array}{l}\text { Diálogo desencadeado a partir da interação dos visitantes } \\
\text { com a exposição e/ou os módulos expositivos, seja sobre seu } \\
\text { funcionamento, design e/ou experiência museal. }\end{array}$ \\
\hline $\begin{array}{l}\text { Conversas em que se faz } \\
\text { associação com experiências } \\
\text { anteriores e vivência pessoal }\end{array}$ & $\begin{array}{l}\text { Mobilização, utilização, questionamento sobre seus próprios } \\
\text { conhecimentos, crenças, rituais, modos de vida, na experiência } \\
\text { museal, fazendo referência a vivências da infância, conhecimentos } \\
\text { da escola; referências a filmes, livros, séries e programa de TV etc. }\end{array}$ \\
\hline
\end{tabular}

Fonte: Adaptado de Massarani et al., 2019a; Massarani et al., 2019b; Massarani et al., 2019c; Massarani et al, 2020.

Com esse material codificado nessas categorias e descrito (a seguir), realizamos a análise qualitativa a partir de referenciais teóricos, especificamente voltadas à comunicação da ciência sobre questões que perpassam por tópicos sobre ciência e religião, temáticas controversas e sociocientíficas. Analisamos as experiências mais frequentes a partir de três tipologias livremente adaptadas do estudo de Navas-Iannini e Pedretti (2017). Esse estudo versa sobre as distintas formas de engajamento de visitantes em uma exposição considerada de temática controversa:

1. Explicando e transmitindo: o modelo de déficit: a comunicação é realizada, principalmente, de forma linear protagonizada pelos mediadores que fazem uma explicação expositiva, unilinear, em que eles explicam e os adolescentes escutam - claramente associada ao clássico modelo de déficit da comunicação da ciência.

2. Diálogos com o “eu” e visões plurais: interação em que os adolescentes têm espaço, instigados ou não pelos mediadores, para contribuir com a construção da narrativa da experiência museal, formulando e articulando questões, pontos de vista e trazendo opiniões sobre a sua relação pessoal com as temáticas abordadas pela exposição.

3. Cocriando conhecimento pela participação: engajamento mais participativo do que o diálogo, pois há, também, a oportunidade para que os mediadores e os visitantes adolescentes construam, em certa medida, conhecimento juntos, favorecendo a discussão, aprendizado coletivo e, em certa medida, a deliberação (Navas-Iannini, \& Pedretti, 2017). 


\section{Resultados}

\section{Descrições das interações dos adolescentes}

Neste artigo, focamos em uma análise principalmente interpretativa e qualitativa dos dados, mas para situar o leitor em termos de frequência de presença de códigos, a seguir, apresentamos alguns números, referentes aos códigos mais relevantes para nossa discussão neste artigo. No total dos vídeos, $3 \mathrm{~h} 44 \mathrm{~min} 58$ s de gravação, obtivemos 439 aplicações de códigos, sendo que mais de um código pode ser aplicado a um mesmo trecho de vídeo.

Dada a visita integralmente mediada, a interação dos visitantes com os mediadores aconteceu intensamente ao longo de toda a visita à exposição (77 trechos), assim como a interação dos visitantes com os aparatos expositivos (119), divididos entre: atividade interativa (15), interação contemplativa (93) e leitura de texto na exposição (11). Codificamos, entretanto, pouca interação exclusivamente visitante-visitante (19).

Conversas que abordavam determinado tema científico relacionadas à exposição, discutidos pelos visitantes e mediadores foram constantes ao longo da visita (64 trechos).

Conversas sobre a exposição e temática não científica teve uma significante parcela (43) dado que a exposição traz temas que tratam de cultura, crenças, religião. Conversas que traziam associações com experiências e vivências anteriores dos visitantes também estiveram presentes em número relevante (42). Conversas sobre a exposição, funcionamento, design e/ou experiência museal foram identificadas em 27 trechos.

Diante desses dados descritivos, é possível constatar que a visita dos adolescentes ao EC foi marcada, principalmente, pela interação contemplativa da exposição e pela interação com os mediadores, o que oportunizou conversas sobre temas abordados pela exposição e sobre a própria exposição e seu funcionamento, design e experiência museal.

Um primeiro aspecto interessante é que as interações exclusivas entre "visitantevisitante" e "visitante-módulo expositivo" ocorreram em poucos momentos: as interações dos jovens entre si e com o EC foram, em sua grande maioria, moduladas e acompanhadas pelos mediadores. Uma das razões para isso é que a secção do museu visitada pelos adolescentes apresenta poucas oportunidades para a interação física, pois não há um grande número de módulos expositivos que estimulem e necessitem de ações como manipular, tocar, apertar botões, girar manivelas, ou outras ações necessárias para a continuidade da narrativa/enredo/conteúdo: identificamos apenas 15 momentos com este tipo de interação. Ao contrário, a configuração expográfica favoreceu a interação contemplativa - muito presente neste estudo ( 93 trechos) - e as conversas sobre a temática da exposição.

As conversas foram, de fato, componente fundamental das visitas e nos permitiram analisar e discutir como os jovens se relacionaram com temáticas controvérsias e sociocientíficas, como as discussões se constituíram pelo entrelaçamento entre ciência, cultura, religião e trajetórias de vida, destacando o papel do mediador como fundamental para o fomento desses assuntos. Focamos, então, na análise a seguir, nas conversações instigadas pela própria exposição e/ou pelo mediador, dada a sua predominância e relevância do conjunto de dados coletados neste museu. 


\section{Conversações sobre ciência, cultura e religião}

\section{Explicando e transmitindo: o modelo de déficit}

Ao abordar as concepções sobre a origem do Universo e da vida humana, e as discussões sobre quem somos e o que nos diferencia dos demais seres vivos, a exposição focaliza, principalmente, em questões históricas, antropológicas, filosóficas e sociológicas. Seu desenho expográfico se configura por aparatos de pouca interatividade física, tais como painéis, dioramas, textos em formato impresso e audiovisual, e consequentemente, levando a uma interação mais voltada para a contemplação, leitura e diálogo, seja com os outros visitantes ou com o mediador.

Em muitos casos, observamos que a atitude assumida pelos mediadores durante a interação com os visitantes de é mais de explicar e menos a de escutar. Isso é concretamente é evidenciado pelos dados quantitativos: alta presença da interação contemplativa ao longo da visita (93 trechos) e de interação visitantes-mediadores (77). Essa relação visitante-mediador se dá muitas vezes em via de mão única, do mediador para os adolescentes. Para ilustrar, trazemos o exemplo 1 com um longo trecho de exposição oral do mediador sobre a origem do universo na perspectiva dos gregos:

Exemplo 1 (G2):

- M: Os gregos acreditavam que há muito tempo existia uma coisa chamada Caos, só que esse Caos era como se fosse o nada. Mas ao mesmo tempo esse Caos podia ser tudo. Então, o nada e o tudo estavam misturados. Desse Caos surgiu aquela moça ali, que era a própria Terra, e recebia o nome de Gaia. Era uma Terra plana, sem a forma que a gente conhece hoje dela. De repente, Gaia começa a sentir uma dor muito forte na barriga, abre para ver o que era e de dentro sai o céu, que era Urano. Só que Urano olhou para Gaia e se apaixonou por ela e os dois passaram a manter uma relação. Todos os dias Urano chovia sobre Gaia e dessa chuva foram surgindo os seres chamados Titãs. Já ouviram falar deles?

- Visitantes: Aham.

- M: Só que tinha um problema. Urano tinha muito ciúmes desses Titãs. Então, ele resolveu fazer abrir a barriga de Gaia e vai mandando todos os Titãs que nascem lá para dentro. De repente, Gaia, que era sem forma, começa a ganhar uma forma e vai ficando mais ou menos como que a Terra é hoje. Meio oval, não é?

- V3: Geóide.

- M: Um Geóide.[...]Existia no meio desses Titãs um rapaz chamado Cronos. Já ouviram falar dele?

- Visitantes: Já.

- M: Cronos era o titã do tempo e, além disso, tinha certa revolta.[...] Ele chama Gaia e entrega uma ferramenta, que era uma foice, e diz: "Quando Urano estiver se aproximando de você, corta o símbolo da força de Urano". Então, quando Urano vai se aproximar de Gaia, ela pega essa foice e corta o "bilau" de Urano.[...] O pênis dele cai nas espumas do oceano e [...] tem o nascimento da deusa do amor.[...] As gotas de sangue 
de Urano que caíram sobre a Terra fez surgir os gigantes.[...] Cronos tinha falado para mãe: "Se você derrotar o Urano, eu vou ajudar a libertar os meus irmãos". Só que ele não libertou.[...] Gaia lança sobre ele uma maldição. Ela fala para Cronos: "Você não cumpriu sua promessa, e um dos seus filhos vai fazer a mesma coisa que você com seu pai". Vai se passar muito tempo e [...] Cronos vai se apaixonar por outra deusa, chamada Reia. Eles tiveram bebezinhos,[...] mas Cronos tinha medo da profecia [...] e engolia as crianças. Então, essa é ideia do tempo. O que ele faz com a gente? Ele vai passando e devorando a nossa vida. É mais ou menos essa a ideia de Cronos devorando seus filhos. Reia vai descobrir que está grávida e [...] quando ela tem esse bebê, ela leva para uma ilha e dá para Cronos um bando de pedras. Ele engole as pedras achando que estava engolindo o filho. Só que essa criança vai crescer na ilha [....] e vai receber o nome de Zeus. Zeus vai crescer, ficar forte [....], luta com o pai e consegue tomar o poder. No meio dessa confusão, existia um titã chamado Prometeu, que pega o barro e faz o homem mortal. Só que Prometeu rouba o fogo e dá para essa humanidade. Zeus fica nervoso e resolve castigar a humanidade. Então, ele cria a primeira mulher e dá o nome de Pandora. Pan significa "todos" e Dora, "presente". Ela tinha todos os presentes. Ele dá a ela uma caixinha e diz o seguinte: "Você vai levar esse presente para a humanidade, mas você não deve abrir a caixa". Só que existe uma coisa no ser humano chamada curiosidade. E o que aconteceu? Pandora abriu a caixa e liberou várias coisas ruins e, quando percebeu o que estava acontecendo, viu que estava surgindo doenças e tudo mais, ela fecha a caixa. Os gregos falam que ficou um item preso lá e dão o nome de esperança. Pode ser uma coisa que vai sair da caixa e fazer o mundo ficar perfeito ou pode ser que a esperança, quando sair da caixa da Pandora, destrua o mundo de uma vez por todas e ser a vingança completa de Zeus. Assim os gregos acreditam que foi surgindo o mundo e os seres humanos.

Ao ler esse longo trecho de fala, lembramos que as visitas aconteceram em torno de 50 minutos cada e que o trecho (transcrito com alguns recortes) é referente a mais de 10 minutos, isto é, cerca de $20 \%$ da experiência museal desse grupo aconteceu nesse espaço em que o mediador assume o protagonismo e deixa pouco espaço para as interferências e opiniões dos visitantes. Uma consequência direta dessa ação é a dificuldade do mediador trazer os adolescentes para a conversa e de incitar seu engajamento, como vemos no exemplo 2 (sequência do exemplo 1):

Exemplo 2 (G2):

- M: E aí, o que vocês acham dessa história?

- V4: Eu acho legal.

- V1: Eu também acho legal.

- M: Você acha legal? Vocês acham diferente do que a gente tem?

- V1: Pelo que a gente está acostumado, sim.

- M: Pelo que a gente está acostumado, sim, né? Todas essas histórias, geralmente, eram contadas, por isso a gente tem essas vozes. Vocês perceberam que algumas são uma espécie de música? 
- Visitantes: Aham.

Situação semelhante aconteceu com os G3, em que após longo trecho de exposição da mediadora sobre as diferentes histórias contadas pelos povos ela tenta uma interação com o grupo, sem muito sucesso:

Exemplo 3 (G3)

- Ma: Não sei o que vocês acharam.

- V1: Muito legal.

- Ma: Essa cosmogonia aqui, na verdade, são várias histórias femininas, que são contadas a partir da ciência. [...] Da mesma forma que a gente tem essas histórias contando sobre a origem do mundo, a gente tem a da ciência. Vocês acham que tem diferença entre elas?

- V1: Acho que sim.

- Ma: Qual a diferença que vocês acham?

- V3: Não sei dizer.

- Ma: Vocês acham que qual está mais certa, a ciência ou as religiões?

- V3: Eu acho que a religião.

- V1: A religião.

- Ma: Essa sala é legal, porque não tem uma resposta definitiva. Ela mostra que tem várias histórias, mas ela não chega a contar uma que está correta, porque cada pessoa tem uma história que faz sentido. Então, a gente não precisa ficar competindo.

- V1: Isso é muito legal.

Este é um exemplo de invisibilização da controvérsia, e do possível conflito, por parte da mediadora. Como no Espaço do Conhecimento havia um histórico de alunos e professores criacionistas questionando a seção sobre mito, e também a exposição sobre evolução biológica, é possível que os mediadores se sintam mais confortáveis em buscar uma narrativa conciliatória, que impossibilite o embate. Contudo, se perde assim uma oportunidade importante para o diálogo, o aprendizado e a construção de uma relação produtiva entre um espaço de divulgação científica e seu público. Neste caso, a mediadora, em vez de atuar como catalisadora da discussão importante, e que costuma ser trazida pelo público, das relações entre saberes tradicaionais, religião e ciência, ela encerra o debate, antes mesmo de abri-lo, afirmando que se trata de "várias histórias" que não precisam "competir". Não só: em vez de explorar o fato de que ciência, mito, religião são formas distintas de produção de conhecimento, com funcionamento e funções diferentes (e não "histórias"), colocar tanto a teoria do Big Bang, quanto as cosmogonias, apenas como opiniões, gera no público uma visão simplista de relativismo e não contribui para uma compreensão real das especificidades da ciência e do mito.

Esses exemplos mostram também que parte importante da experiência dos adolescentes foi marcada por interações comunicativas de tipo linear e transmissivo, associado àquele que, nos estudos sobre comunicação pública da ciência, tem sido chamado "modelo de déficit" ou "teoria do déficit". O modelo de déficit é uma abordagem na divulgação científica em que se assume que o público precisa, antes do que tudo, de 
informações e conhecimentos que não possui e que, portanto, a comunicação deva ser construída, principalmente, "de quem sabe" para "quem não sabe". Assim, assume-se um emissor (sejam os especialistas consultores da exposição, os curadores ou os mediadores do museu) que sabe de antemão tudo o que énecessário explicar e transmitir e um receptor (os diversos tipos de públicos) substancialmente passivo e ignorante (Hilgartner, 1990; Miller, 2001). Soma-se a esse modelo de comunicação da ciência, uma forte tendência de um estilo de mediação, que pode refletir, também, a concepção educativa/comunicativa da instituição: o estilo que Marandino (2008) define como "visita-palestra" - aquela em que ocorre o aprofundamento de um tema da exposição por um especialista ou educador e tem baixo nível interacional.

Apesar das inúmeras críticas ao modelo de déficit e às "visitas-palestra" na literatura, vale, entretanto, fazer algumas reflexões. Se por um lado, existem diversas críticas a esse modelo - como ao não considerar o papel ativo dos públicos, suas competências e demandas (Lewenstein, 2002) - , por outro, entendemos que saber transmitir informação é uma parte relevante (embora não a única importante) no comunicar a ciência. Se os mediadores, por exemplo, são capacitados para fornecer explicações interessantes, claras, inspiradoras ou divertidas, uma abordagem menos dialógica pode ter, em determinados momentos e espaços, sua função, especialmente, se complementada com momentos de escuta e debates, e se em secções onde de fato os temas tocados não são muito conhecidos pelos visitantes. Dickson (2005, s. p.) argumenta que é necessário tomar cuidado para não descartar alguns aspectos relevantes que são valorizados pelo modelo de déficit e sintetiza: "Um diálogo democrático sobre questões de ciência é fundamental nas sociedades modernas; mas fornecer informação confiável de uma forma acessível é um pré-requisito fundamental para que isto ocorra”.

Assim, em concordância com Navas-Ianinni e Pedretti (2017) e com a reflexão de Levinson (2010, p. 80), acreditamos que "[...] quando inserido em práticas democráticas, o modelo de déficit pode empoderar aqueles que estão participando da deliberação por meio da comunicação de conhecimentos apurados e robustos em termos compreensíveis". Entretanto, nesses casos apresentados nos exemplos 1, 2 e 3 em vez de incentivar o debate, a narrativa do mediador afastou os adolescentes que preferiram não desenvolver suas ideias a respeito do proposto e não tiveram a possibilidade de entender que as controvérsias sociocientíficas sobre mitos de origem da vida e da humanidade não precisam implicar numa rejeição da ciência, ou da religião, e tampouco num relativismo em que as narrativas da ambas sejam apenas opinião individual.

Apesar da presença marcante de momentos de transmissão unidirecional no EC, em grande parte por causa da natureza expográfica e da visitação com o foco muito centrado no mediador, as temáticas da exposição, ao dialogar diretamente com questões de crença, cultura e religião, oportunizam uma conexão direta com controvérsias sociocientíficas, bem como com as experiências, as práticas, e as perspectivas culturais dos visitantes, o que facilita a participação e a formulação de opiniões. 


\section{Diálogos com o "eu" e visões plurais}

$\mathrm{Na}$ análise dos vídeos, observamos que há trechos que vão além do protagonismo e exposição oral dos mediadores. São visíveis esforços para promover o diálogo e o questionamento junto aos adolescentes, dando espaço para emissão de opiniões, trocas e visões plurais, promovendo um segundo estilo de mediação, o da a "discussão dirigida", em que "a mediação se faz por meio de questionamentos, de forma a proporcionar o entendimento de aspectos comunicacionais pertinentes àquela exposição" (Marandino, 2008, p. 23). Em sobreposição com práticas associadas às teorias de déficit, houve então a possibilidade de o mediador fazer uma abordagem dialógica e democrática, do tipo que foi valorizado, especialmente a partir da década de 1990, nas discussões teóricas e metodológicas sobre modelos de comunicação pública (Miller, 2005).

Apesar de termos observado, durante as visitas, trechos longos da exposição marcados por explicações unilaterais, os adolescentes - em grande parte instigados pelos mediadores - também tiveram espaço para contribuir com a construção da narrativa da experiência museal, formulando e articulando questões, pontos de vista e trazendo opiniões sobre a sua relação pessoal com as temáticas abordadas pela exposição. Esses momentos de troca e emissão de opinião, descaracterizam a natureza puramente deficitária da comunicação da ciência, assim como argumentado por Navas-Ianinni e Pedretti (2017).

Modelos dialógicos de comunicação da ciência favorecem um ambiente rico para que os conhecimentos dos cidadãos sejam vistos e valorizados e enriquecem o debate e a problematização de questões sociocientíficas e controversas. Histórias e posicionamentos pessoais refletem pontos de vista, dilemas éticos, preocupações morais, medos, sonhos, crenças, e essas questões são ainda mais aprofundadas quando a exposição do EC propõe a abordar questões relacionadas com ciência, religião, cosmogonias e os mediadores fomentam essas discussões.

Observamos que, na exposição analisada, a natureza dos temas expostos gerou oportunidades para histórias pessoais e para o dissenso, relevantes para o engajamento do público (Navas-Iannini, \& Pedretti, 2017). Dessa forma, na medida em que os jovens manifestam seus pontos de vista sobre esses temas, eles trazem à tona suas crenças pessoais, sua visão de mundo, e a opinião do "eu". Contudo, se torna, de novo, evidente nestes momentos, o quanto o museu não está preparado, em sua expografia, para tratar situações controversas, e como falta uma capacitação para que os mediadores compreendam plenamente a natureza de uma controvérsia sociocientífica, e sua diferença com um uma controvérsia interna ao campo científico.

Os exemplos a seguir ilustram essa dimensão. No G4, no início da visita e posicionados em frente ao módulo expositivo Origens e Extratos do tempo, a mediadora pergunta se os jovens já haviam estudado sobre o surgimento do universo. O V1, imediatamente, responde que "sim" e traz para a discussão a teoria do Big Bang. Em seguida, a mediadora questiona se eles acreditam nessa teoria e o mesmo adolescente diz: "Eu acredito. Eu sou católico, mas acredito". Ao abordar a questão da religião logo 
na primeira parte da visita e usar o termo "mas", ele explicita sua consciência de que há aí alguma contradição ou controvérsia, e que, em sua concepção, sua religião e a teoria científica atualmente mais aceita sobre o surgimento do universo podem não coincidir. As outras visitantes do grupo, também, expõem suas opiniões, inclusive a mediadora, como vemos no exemplo 4.

Exemplo 4 (G4):

- Ma: A nossa exposição é a mesma no quarto e no terceiro andar. Ela se chama Demasiado Humano. Vocês acham que significa o quê? Demasiado é como se fosse “muito". É uma coisa que é muito humana. Para vocês, o que torna a gente humano?

- Visitantes: A vida.

- V1: Consciência.

- Ma: Mas e os outros animais que também têm vida? Será que a nossa consciência é diferente?

- V1: Provavelmente.

- Ma: Então, cada pessoa tem uma resposta diferente. Não tem um certo ou errado. [...]. Não sei se vocês já se fizeram a pergunta "De onde a gente veio".

- V1: Já. Várias vezes.

- Ma: “Será que Deus existe ou não existe? Será que existe vida após a morte ou vida fora da Terra?”. Então, para ele, o ser humano nasce com um monte de questionamentos e, à medida que a gente vai crescendo, a gente vai construindo conhecimentos para responder a essas perguntas que todo mundo faz. Nesse andar a nossa pergunta é "Como o universo surgiu? Qual a nossa origem? De onde a gente veio?". Só que a resposta que a gente tem aqui é do ponto de vista da ciência. A gente tem várias outras. Para cada pessoa tem uma explicação diferente. E essa aqui é mais a científica. Vocês já estudaram como surgiu o universo?

- Visitantes: Já.

- Ma: Vocês acham que veio de onde?

- V1: Pelo Big Bang.

- Ma: Big Bang? Vocês acreditam nessa teoria?

- V1: Eu acredito. Eu sou católico, mas acredito.

- Ma: Vocês também? [pergunta para as outras visitantes]

- V2: Não.

- V3: Eu não deixo de acreditar, mas sei lá. Eu acho que foi as duas coisas.

- Ma: Pode ter sido. Cada um fez uma parte. Tem muita gente que fala. É bem legal. A ideia da exposição não é falar que uma forma é melhor do que a outra. Eu mesma não sei se acredito no Big Bang. Não sei direito como o mundo surgiu. Mas aqui tem uma explicação. Como tudo aconteceu? [segue com uma breve explicação sobre o Big Bang].

Como se vê, neste caso é evidente o esforço para a escuta e a construção de um diálogo, não apenas entre opiniões pessoais, mas que incorpore informações e conhecimento trazidos pelo público. Contudo, a falta de material, na exposição, para dar 
consistência e contexto a esta discussão, o pouco tempo à disposição para que o próprio mediador faça isso, e um conhecimento insuficiente sobre o funcionamento da ciência e das controvérsias sociocientífica, torna o diálogo menos produtivo. Isso porque em vez ser direcionado para uma compreensão das causas da controvérsia, foca numa solução "pacífica" que a própria mediadora sintetiza com "eu mesma não sei se acredito no Big Bang”, perdendo de vista que o que está em jogo no tratamento de uma controvérsia.

Já no exemplo 5, do G5, os diálogos são estimulados por perguntas e dúvidas trazidas pelos adolescentes a partir da narrativa da mediadora. Depois de a mediadora narrar o mito de criação do povo Maxacali a V2 questiona se a comunidade foi preservada. Na sequência após o mito de criação Iorubá descrito pela mediadora e V1 pergunta se é de alguma parte específica do Brasil. Em ambos os casos essa interação e a abertura da mediadora para as perguntas dos adolescentes deu a oportunidade não apenas de detalhar e aprofundar sobre a cultura, mas também de modular a experiência museal e o aprendizado por um caminho que não estava pré-estabelecido pelo museu ou o mediador, mas desenvolvendo questões e demandas pertinentes formuladas pelos próprios visitantes.

Exemplo 5 (G5):

- Ma: Então, essa cosmogonia aqui é muito legal. Os Maxacalis acreditam que essa é a história, o mito de criação, do povo deles e não do mundo inteiro. Tem algumas histórias que acham que aquela história é a verdadeira. Eles, não. Isso é interessante. Eles não impõem a história deles para outra pessoa, eles só sabem que aquela é a história deles e pronto. Não tem problema nenhum com as outras. Às vezes, tem algumas outras que são intolerantes. Então, aqui havia apenas um índio na floresta e um dia ele fez sexo com essa sereia de barro aqui [... continua narrando a história]. É assim que eles acreditam que a comunidade deles foi criada.

- V2: Essa comunidade foi preservada?

- Ma: É. Mas assim, hoje está toda modificada, se for parar para pensar. Alimentação, ambiente já não é mais como antes. Mas eles estão lá firmes e fortes.

— V1: Todas essas caixas de som é a história sendo contada?

- Ma: Isso. Na língua original. Essa aqui também é muito interessante, que é a cosmogonia iorubá. Aqui a gente tem o Olodumarê e o Obatalá. Obatalá manifestou o desejo de criar a terra firme. [... continua narrando a história]. É assim que eles acreditam que o mundo foi criado. Essas duas histórias são muito presentes no Brasil, né? As pessoas confundem, às vezes. Aqui é o mito de criação Iorubá. Só que isso aqui deu origem a algumas religiões - candomblé, umbanda - mas não é uma religião.

- V1: Mas ela é de alguma parte específica do Brasil?

- Ma: Não. Essa aqui é lá da Nigéria, mas veio para cá. Essa aqui faz parte de uma cultura. Tem a filosofia, tem tudo ali. Não é só a religião. Nenhuma dessas histórias, na verdade, é uma religião. [...]

Interessante notar também, nesses diálogos com o "eu" — ou seja, as reflexões dos próprios adolescentes sobre suas crenças e possíveis conflitos - como eles se relacionam com a ciência e religião e reforçam a discussão de Mota (2013) sobre a aceitação dos 
jovens das explicações científica e religiosa para a origem do universo e da vida humana. Ou seja, a sua própria religiosidade não impediu de acreditar na evolução biológica e de outras visões de mundo; e que, tampouco, implica em abrir mão de suas crenças religiosas.

$\mathrm{Na}$ visita ao EC, momentos de escuta e diálogo modulados pelos mediadores, também mostram aspectos que Bubela et al. (2009) apresentam como importantes para modelos dialógicos de comunicação da ciência: a pluralidade de opiniões. No exemplo 6, há trechos de opiniões e questionamento dos visitantes sobre as explicações científicas:

Exemplo 6 (G4):

- Ma: A Terra, no início, era um pouquinho diferente de como ela é hoje.

- V1: Ela se chocou com a Lua, né?

- Ma: Aham. Vocês já ouviram essa teoria?

- V1: Já.

- Ma: Como que é?

- V1: Parece que veio um meteoro muito grande que se chocou com a Terra e formou a Lua.

- Ma: É bem isso. É esse planeta aqui, que eles chamavam de Teia. Ele se chocou com ela. Só que, na verdade, a gente não sabe como que a Lua se formou. Existem várias teorias. Há muito tempo, as pessoas achavam que a Terra girava tão rápido que um pedacinho dela se desgrudou de repente e começou a flutuar em volta dela e virou a Lua. Hoje, já tem outra teoria que fala que tinham vários planetas bem menores, meteoritos mesmo, que foram caindo na Terra e acabaram levantando uma nuvem de poeira. Essa nuvem de poeira começou a se juntar e, aos poucos, foi se formando a Lua. Mas essa teoria que você falou é a mais aceita.

- V3: Só que não faz muito sentido, né?

- V1: Nem tudo precisa fazer sentido. [...] Tem aquela teoria também de que caiu um meteoro com...

- Ma: Ah, os cometas. Os cometas são feitos de gelo e, há muito tempo, as pessoas achavam que caia muito mais cometas do que cai hoje, e eles foram trazendo água para a Terra.

A discussão acima mostra que a pluralidade e o diálogo são explicitados não só pelas opiniões ou crenças dos atores que estão na visita à exposição (dos mediadores e dos visitantes), mas também por fatos, noções, hipóteses científicas que eles trazem para a experiência museal, a partir do debate. Tal contraponto e polifonia de vozes é fomentada pela exposição e poderiam ser mais aproveitados por uma mediação museal capacitada para lidar com as controvérsias, fazendo aterrizar o debate entre visitantes em fatos concretos e dando mais oportunidade para que eles aprofundem temas a partir de buscas de evidência, comparação de hipóteses, questionamento de afirmações.

No exemplo 7, um dos visitantes expressa que acha interessante a diversidade de cada cultura ao representar a origem de criação do universo e da vida. Também fica em evidência a atitude do mediador ao instigar que não há uma forma única de fazer 
essa narrativa e que, inclusive, as explicações científicas também vêm de uma produção social e coletiva, inserida em uma cultura, mas com uma especificidade: a de escolher explicações que lidem com evidências empíricas.

Exemplo 7 (G1):

- M: Vocês perceberam que aqui é um espaço dessas histórias. Você tem a judaico-cristã, a grega, a maia, a Maxacali do norte de Minas e a Iorubá da Nigéria[...]

- V2: É, tipo, a cultura de cada um?

- M: Isso. Isso aqui são chamados Cosmogonias, que são histórias sobre a origem do universo de acordo com cada povo.[...]

- V1: Mas eu acho interessante, porque mostra a forma de eles verem o mundo.

- M: Eu acho muito legal, porque, de certa forma, isso é uma representação que eles usam para poder explicar a origem.[...] Vocês têm que pensar que é uma coisa que é normalizada para eles. Por exemplo, [...] eu não acredito na história de Adão e Eva. Para mim, ela é estranha.

- V4: A nossa também não faz muito sentido.

- V1: É um pouco estranha.

— M: Elas têm um sentido que é o de tentar explicar [...] O Big Bang não é uma história também? Vocês acreditam que seja?

- V1: Sim, é uma história.

- M: Mas é uma história que tem algumas provas para sustentar. Mas nem tudo está comprovado. Isso a gente pode pensar o seguinte: é da nossa cultura agora entender que a explicação do universo pode ser feita daquela forma que a ciência faz. É uma parte da cultura a ciência também. Entende?

\section{Co-criando conhecimento: comunicação como participação}

Uma terceira forma de comunicação entre mediadores e visitantes, ainda mais participativa, foi observada em nossos vídeos, porém em menor escala que as anteriores. Nas visitas dos adolescentes, as discussões e controvérsias trouxeram a oportunidade para que os mediadores e os visitantes adolescentes construíssem juntos, em certa medida, a experiência museal e o aprendizado. Houve, para isso, uma predisposição dos mediadores, evidente em alguns momentos da visita.

No G4, por exemplo, a mediadora se apresenta para os adolescentes dizendo que é estudante como eles, estabelecendo uma comunicação não hierárquica e explicitando que está aberta para trocas:

Exemplo 8 (G4):

- Ma: [...] podem ficar à vontade para perguntar, comentar. Eu também sou estudante igual a vocês, então, não quer dizer que eu saiba mais do que vocês. Qualquer coisa que quiserem comentar, podem ficar à vontade.

Navas-Ianinni e Pedretti (2017) informam que um dos padrões para se caracterizar a co-construção de conhecimento pela participação é a redistribuição de papéis durante a visita. Com o G5, exemplo 9, a mediadora adota a estratégia de deixá-las primeiro 
observar os dioramas da exposição para depois conversarem a respeito. Essa estratégia parece interessante para fomentar o diálogo uma vez que o momento de observação das adolescentes suscitou a curiosidade, compartilhada entre elas mesmas e vieram com perguntas para a mediadora que, por sua vez, pode explorá-las trazendo mais elementos para o processo de comunicação:

Exemplo 9 (G5):

- Ma: Vamos fazer assim? Acho que vai ser legal primeiro vocês ouvirem, darem uma olhada rapidinho e depois a gente conversa. Para a gente ter uma noção do que vocês vão pensar. [Adolescentes observam os dioramas]

- V1: Isso é o nome da tribo?

- Ma: Essa é a comunidade Maxacali. É uma comunidade originária aqui do norte de Minas. Hoje, a gente não usa mais o termo tribo. Usa mais o termo comunidade, é mais adequado.

- V2: São coisas para a origem? Explicando a origem.

- V1: Sim.

- Ma: Conseguiram pegar mais ou menos o que fala aqui? Tem uma noção?

- V1: Não.

- V3: A V1 deu um chute de ser da criação.

- Ma: Isso. Aqui são as cosmogonias, que são os mitos de criação do universo, do ser humano e diversas culturas. Então, a gente tem ali a cosmogonia iorubá, que é na Nigéria; a cosmogonia maxacari aqui em Minas Gerais, que é uma comunidade indígena; a cosmogonia maia-quiché, que é ali na América Central; cosmogonia grega e a cosmogonia judaico-cristã. Então, cada cultura vai ter uma diferente explicação da criação do universo, do ser humano. Tem alguma aqui que vocês conhecem?

- V1: A grega. Essa daqui. [Aponta para o diorama da judaico-cristã].

- V2: Essas primeiras a gente não conhecia. [Voltam a observar novamente]

No exemplo 10, do mesmo grupo, a adolescente, instigada pela mediadora, explica sua hipótese e opinião sobre o motivo da cultura Maxacali não ser conhecida pelo grupo, demonstrando uma reflexão sobre o que estava vivenciando e relacionando com seu contexto social e suas experiências prévias:

Exemplo 10 (G5):

- Ma: O interessante aqui é a gente pensar nisso, nessa diversidade cultural. Isso é muito importante por quê? Por exemplo, a cosmogonia Maxacali é aqui do norte de Minas, do nosso estado, e a gente nunca ouviu falar. Faz parte da nossa cultura e isso é muito importante. Por que vocês acham que a gente nunca ouviu falar dela?

- V2: Eu acho que ela é velada.

- Ma: Velada? Mas por quê?

- V2: Porque a gente chegou e tomou o lugar deles. A gente chegou, ocupou as terras e foi impondo a nossa cultura e por causa disso, para poder ficar mais fácil para a gente, a gente foi deixando as coisas deles de lado. É injusto, mas foi o que aconteceu.

- Ma: Isso é muito sério, porque acaba que essa comunidade vai perdendo 
espaço. Na verdade, a gente deveria estudar, porque isso faz parte da nossa história. A gente estuda em história, por exemplo, muito mais a Europa do que a nossa própria história.

Ao dar a sua própria explicação para um questionamento da mediadora, há uma reflexão e uma crítica social da adolescente. Fica evidente que nesse episódio o conhecimento, mesmo que de forma limitada, é co-criado por meio de uma interação aberta e do diálogo, que são moldados pelos mediadores e visitantes a partir de suas necessidades e preocupações sociais, ao invés do que por currículos e textos prépreparados. Assim, em diversos momentos os adolescentes são vistos como cidadãos “cujas vozes são autênticas e escutadas" (Levison, 2010, p. 10). Observamos também que o espaço da co-criação em uma prática democrática de comunicação da ciência abre espaço para a ponderação dos adolescentes sobre sua própria vida e contexto social, indo além das questões controversas abordadas pela exposição. Há evidências nas discussões que os jovens conseguem fazer perguntas, conexões e expressar preocupações a respeito das propostas da exposição e da mediadora.

Por fim, trazemos o exemplo 11 de quando o G5 está no módulo expositivo Cosmogonias. A mediadora questiona se as adolescentes conhecem e acreditam na cosmogonia judaico-cristã e uma delas responde que ela e a outra visitante sim. A adolescente parte para uma explicação sobre o que está sendo representado e expõe sua visão sobre "criacionismo" e "evolucionismo" - conceitos trazidos pela própria visitante, reforçando a oportunidade de co-criação.

Exemplo 11 (G5):

- Ma: Vocês conhecem a história mais ou menos, né?

- Visitantes: Sim.

- Ma: Vocês acreditam?

- V2: A gente acredita na judaico-cristã, eu e ela.

- Ma: Ah, tá. E como é que é essa história?

- V2: Aqui está representado Adão e Eva no Éden. Simplesmente, Deus fez o Éden e, depois de Adão, fez o universo. É bem místico, né? Não é que exatamente nós acreditamos desse jeito, é o que é usado para explicar, mas a gente, pelo menos eu particularmente acredito, que tem uma mistura desse "criacionismo" com o "evolucionismo". A ciência consegue explicar muitas coisas, mas tem uma hora que trava. E aí, acho que entra aí.

\section{Considerações finais}

Neste estudo, em que buscamos compreender como se deu a relação entre adolescentes e mediadores na exposição "Demasiado Humano" do Espaço do Conhecimento da UFMG, observamos que duas das três relações fundamentais do triângulo pedagógico que caracterizam uma experiência museal (Allard et al., 1998) foram de maior recorrência: as relações entre "visitante-módulo expositivo" e "visitantemediadores”. A terceira relação, "visitante-visitante”, ocorreu em menor número, dado 
que os adolescentes interagiram pouco somente entre si, em grande parte, porque as visitas foram integralmente guiadas por mediadores. Assim, a alta frequência da relação visitante-mediador revela a concepção de mediação do EC centrada na visita guiada. Se, por um lado, acreditamos que a interação entre visitantes e mediadores é uma oportunidade para incrementar e fomentar a discussão e troca sobre questões potencialmente controversas, como discutimos ao longo do texto, por outro lado, também vale problematizar o pouco espaço que os adolescentes tiveram para conversar apenas entre eles e tomar suas decisões de percursos. Diversos estudos sinalizam e valorizam a importância da livre-escolha nos espaços de educação não formal (Dierking, 2004) e das trocas sociais, do diálogo e da construção do conhecimento entre os próprios visitantes (Allen, 2002; 2004).

Exploramos, assim, como a exposição foi experienciada pelos adolescentes e como os mediadores catalisaram (ou não) espaços para emissão de opiniões, trocas, reflexão e coconstrução de conhecimentos. Além de a expografia abordar temas que perpassam ciência, religião e cultura de forma transversal e transdisciplinar, é importante lembrar que o potencial de tratar dessas temáticas de maneira a fomentar participações dialógicas e democráticas dos públicos também se deve, em parte significativa, à capacitação e atuação dos mediadores. Nos vídeos analisados, fica evidente que no EC os mediadores tiveram papel fundamental ao modular os formatos de comunicação da ciência.

Uma discussão que sobressai a partir desses dados é a relevância da formação desses profissionais para realizar esse tipo de comunicação da ciência e para atuar com controvérsias e mediar diferentes opiniões que emergem dos visitantes. É necessário repensar e questionar o papel da capacitação continuada dos mediadores, que agem como facilitadores que fazem uso de estratégias de comunicação para criar pontes entre diferentes esferas socioculturais. Existem experiências de formação sendo feitas de forma a levar em conta outros aspectos para além do tema/conteúdo tratado na exposição, entretanto, no Brasil, Contier (2018, p. 234) visualiza que, em geral, o que se encontra é "uma formação [...] que valoriza o saber e os conteúdos, e que ainda está muito distante de trabalhar com os educadores as estratégias para lidar com as reações emocionais do público". Por essa razão, defendemos a necessidade de desenvolver estratégias e explorar a formação continuada desses profissionais, dado que trabalhar com controvérsias junto ao público envolve diversos desafios que devem ser explorados ao longo da sua atuação profissional (Contier, 2018).

Sobre o formato da comunicação da ciência, destacamos que as experiências dos adolescentes com os mediadores variaram entre trechos da visita focadas no modelo de déficit a trechos marcados por uma comunicação mais participativa e democrática que oportunizou a emissão de opiniões, reflexões sobre questões controversas envolvendo temáticas de ciência, religião e cultura, conexões com seu cotidiano, questões recorrentes da sua vida, e, ainda, a coconstrução de conhecimento (Navas-Ianinni \& Pedretti, 2017). Ao repensar o modelo de déficit, entendemos que eles foram expostos a informações robustas sobre os trechos analisados da exposição para se discutir a origem do Universo 
e da vida na Terra e como diferentes culturas retratam essa narrativa. Por meio dos módulos expositivos e das trocas com os mediadores, tal como Navas-Iannini e Pedretti (2017), argumentamos que o modelo de déficit foi usado como um modo de dar suporte e embasar processos dialógicos e participatórios por meio da comunicação de informações úteis, a fim de facilitar o surgimento e manutenção de outros modelos de comunicação. Desta forma, acreditamos que as exposições científicas podem reformular o modelo de comunicação baseado no déficit e transformá-lo em uma dimensão de participação democrática em ciência e tecnologia (Navas-Ianinni \& Pedretti, 2017).

Destacamos, contudo, que, apesar da comunicação da ciência em um formato dialógico e democrático e a abordagem de assuntos controversos ainda não serem tão frequentes na realidade brasileira, observamos um grande potencial do Espaço do Conhecimento da UFMG para tal. Trechos específicos dos vídeos demonstram o que é defendido por Navas-Iannini e Pedretti (2017): a exposição e sua mediação forneceram oportunidades para momentos de interação, discussão, aprendizado coletivo e, em certa medida, deliberativo, visto que os visitantes podem participar de forma não-hierárquica e experienciar embates entre diferentes interesses, posições e crenças.

Diante do estudo desta experiência no EC, é importante destacar ainda que reforçamos os apontamentos de Mota (2013): há uma predisposição entre os jovens brasileiros em entenderem a evolução biológica independentemente das suas convicções religiosas e uma atitude positiva quanto às relações entre ciência e religião. As interações analisadas no presente trabalho mostram que é possível, embora desafiador, construir experiências museais com os adolescentes que tornem possível articular conceitos científicos, no contexto de controvérsias sociotécnicas, sem lançar mão uma comunicação unicamente "de cima para baixo", de déficit, ou focada apenas em "corrigir" crenças instituindo um muro entre a ciência e outras formas de produção cultural. Mas, para que isso aconteça de forma fecunda, os museus precisam planejar e pensar conteúdos, dinâmicas das visitas e mediação. Compreender que a função, o sentido e o modo de produção de uma explicação científica sobre origem do universo é diferente daquele de uma cosmogonia, sem cair no relativismo nem na deslegitimação dos outros saberes, podem ser um elemento importante do aprendizado, e um fator importante para evitar a escalação de conflitos, fundado em falsos embates entre ciência e saberes locais, ou entre ciência e religião. Fato esse que foi evidenciado nas discussões, com suas limitações e dilemas, sobre as cosmogonias e origem do universo, pautadas por momentos de escuta e diálogo em que se sobressaíram a pluralidade de ideias e o respeito a diferentes opiniões, mas em que também foi clara a necessidade de um trabalho, por parte do museu, de aprofundamento, com os mediadores, da reflexão epistemológica sobre o funcionamento de uma controvérsia.

Especialmente no contexto atual, marcado pela circulação acelerada de desinformação, e por ataques às universidades, à educação, à ciência, uma abordagem pedagógica ou expográfica simplesmente transmissiva, mostra seus limites. A reconstrução de um pacto de confiança com o público pode encontrar, no tratamento 
dialógico e no desafio de tratar questões controversas nos museus, uma ferramenta fecunda, tanto para a educação em ciências, quanto para o fortalecimento de processos de deliberação e apropriação social da ciência e da tecnologia.

Vale destacar o contexto específico das visitas: os adolescentes estão em grupos de amigos, que possivelmente compartilham ideias comuns e/ou que conhecem e respeitam as ideias divergentes, inclusive sobre religião e ciência. Questionamos se essa visita tivesse ocorrido em contexto diferente, por exemplo, adolescentes com seus pais, religiosos ou não, se encontraríamos mais embates, opiniões divergentes, discordância e até rejeição à exposição.

Por fim, este estudo nos trouxe elementos que corroboram as ideias de Einsiedel e Einsiedel (2004) que defendem que os museus de ciências podem ser "Ágoras modernas" para cidadãos e que, para isso - como também discutem Durant (2004) e Schiele (2008) - são necessárias mudanças no processo comunicativo: tanto com relação às concepções sobre seus públicos quanto sobre como interagir com eles. Em acréscimo, este estudo nos trouxe evidências para afirmar que a reinterpretação do modelo de déficit e a interseção entre os diferentes modelos de comunicação da ciência oferecem uma promissora e potente perspectiva para as instituições museológicas envolver seus visitantes de forma significativa em questões contemporâneas, controversas e complexas. Acreditamos, portanto, que a experiência museal dos visitantes adolescentes no EC mostra que a comunicação dialógica e democrática da ciência e a abordagem de temas potencialmente controversos são possíveis de ser implementadas em museus de ciências e que, assim, essas instituições estarão cada vez mais próximas de ser organizaçõeschave e plataformas para a cidadania científica.

\section{Agradecimentos}

Este estudo foi realizado no escopo do Instituto Nacional de Comunicação Pública da Ciência e Tecnologia (INCT-CPCT) que conta com o apoio da Fundação Carlos Chagas Filho de Amparo à Pesquisa do Estado do Rio de Janeiro (FAPERJ) e do Conselho Nacional de Desenvolvimento Científico e Tecnológico (CNPq) e da Red de Museos y Centros de Ciencia (Musa- Iberoamericana) que tem apoio do Cyted Programa Iberoamericano de Ciencia y Tecnología para el Desarollo. O projeto "Olhar do visitante" foi apoiado pela Proep/Casa de Oswaldo Cruz/Fiocruz. A primeira autora agradece a FAPERJ pela bolsa Jovem Cientista do Nosso Estado. A segunda autora agradece a bolsa produtividade do CNPq e à FAPERJ pela bolsa de Cientista de Nosso Estado. Todos os autores agradecem o Espaço do Conhecimento da UFMG por autorizar a realização da pesquisa e os adolescentes voluntários e seus responsáveis.

\section{Referências}

Achiam, M., \& Sølberg, J. (2017) Nine meta-functions for science museums and science centres. Museum Management and Curatorship, 32(2), 123-143. https://doi.org/10.1080 /09647775.2016.1266282 
Allen, S. (2002) Looking for Learning in Visitor Talk: a methodological Exploration. In G. Leinhardt, \& K. Crowley, Learning Conversations in Museums. Larwrence Erlbaum. Allen, S. (2004). Designs for learning: Studying science museums exhibits that do more than entertain. Science Education, 88(1), S17-S33. https://doi.org/10.1002/sce.20016

Allard, M., Larouche, M. C., Meunier, A. Y., \& Thibodeau, P. (1998). Guide de planification et devaluation dês programes éducatifs. Lei éditions Logiques.

Bandelli, A. (2016). Contextualizing Visitor Participation: Science Centers as a Platform for Scientific Citizenship (Doctoral thesis, Vrije Universiteit, Amsterdam, Netherlands). https://research.vu.nl/en/publications/contextualizing-visitor-participation-sciencecenters-as-a-platfo

Bernard, H. R. (2005). Research methods in anthropology: qualitative and quantitative approaches. AltaMira Press.

Biernarcki, P., \& Waldorf, D. (1981). Snowball sampling: problems and techniques of chain referral sampling. Sociological Methods and Research, 10(2), 141-163. https://doi. org/10.1177/004912418101000205

Brotman, J. S., Mensah, F.M., \& Lesko, N. (2010). Urban high school students' learning about HIV/AIDS in different contexts. Science Education, 95(1), 87-120. https://doi. org/10.1002/sce.20405

Bubela, T., Nisbet, M., Borchelt, R., Brunger, F., Critchley, C., Einsiedel, E., Geller, G., Gupta, A., Hampel, J., Hyde-Lay, R., Jandciu, E. W., Jones, S. A., Kolopack, P., Lane, S., Lougheed, T., Nerlich, B., Ogbogu, U., O'Riordan, K., Ouellette, C., ... Caulfield, T. (2009). Science communication reconsidered. Nat Biotechnol, 27, 514-518. https://doi. org/10.1038/nbt0609-514

Castelfranchi, Y., \& Fazio, M. E. (2021). Comunicación de la ciencia en américa latina: construir derechos, catalizar ciudadanía. In El estado de la ciência: principales indicadores de ciencia y tecnología iberoamericanos/interamericanos 2020 (pp. 145157). OEI-RICYT-Unesco. http://www.ricyt.org/wp-content/uploads/2021/02/ ElEstadoDeLaCiencia_2020.pdf

Contier, D. (2009). Relações entre ciência, tecnologia e sociedade em museus de ciências. 2009 (Dissertação de Mestrado, Universidade de São Paulo, São Paulo). Biblioteca Digital de Teses e Dissertações da USP. https://doi.org/10.11606/D.48.2009.tde-10092009145205

Contier, D. (2018) A ação dos educadores-mediadores de museus e exposições em controvérsias sociotécnicas (Tese de Doutorado, Universidade de São Paulo, São Paulo).

Delicado, A. (2009). Scientific controversies in museums: notes from a semiperipheral country. Public Understanding of Science, 18(6), 759-767. https://doi. org/10.1177/0963662508098577 
Díaz-Moreno, N., \& Jiménez-Liso, M. R. (2012). Las controversias sociocientificas: temáticas e importancia para la educación científica. Revista Eureka, 9(1), 54-70. http:// hdl.handle.net/10498/14624

Dickson, D. (24 de junho, 2005). The case for a "deficit model" of science communication. SciDev.Net. https://www.scidev.net/global/communication/editorials/the-case-for-adeficit-model-of-science-communic.html

Dierking, L. (2005). Lessons without limit: how free-choice learning is transforming science and technology education. História, Ciências, Saúde - Manguinhos, 12(supplement), 145-160. https://doi.org/10.1590/S0104-59702005000400008

Durant, J. (2004). The challenge and the opportunity of presenting unfinished science. In D. Chittenden, G. Farmelo, \& B. Lewenstein, Creating connections. Museums and the public understanding of current research. AltaMira Press.

Einsiedel, A., \& Einsiedel, E. (2004). Museums as agora: Diversifying approaches to engaging publics in research. In D. Chittenden, G. Farmelo, \& B. Lewenstein, Creating connections. Museums and the public understanding of current research. AltaMira Press.

Glăveanu, V. P., \& Lahlou, S. (2012). Through the creator's eyes: Using the subjective camera to study craft creativity. Creativity Research Journal, 24(2-3), 152-162. https:// doi.org/10.1080/10400419.2012.677293

Hilgartner, S. (1990). The Dominant View of Popularization: Conceptual Problems, Political Uses. Social Studies of Science, 20(3), 519-539. http://www.jstor.org/ stable/284996

Hodson, D. (2013). Don't be nervous, don't be flustered, don't be scared. Be prepared. Canadian Journal of Science, Mathematics and Technology Education, 13(4), 313-331. https://doi.org/10.1080/14926156.2013.845327

Lahlou, S. (2011). How can we capture the subject's perspective? An evidence-based approach for the social scientist. Social Science Information, 50(3-4), 607-655. https:// doi.org/10.1177/0539018411411033

Latour, B. (2002). Reflexão sobre o culto moderno dos deuses fe(i)tiches. EDUSC.

Leite, P. (2010). A aventura do conhecimento. In M. AlmeidA, \& P. Leite (Orgs), Demasiado Humano. Editora UFMG.

Levinson, R. (2010). Science education and democratic participation: An uneasy congruence?. Studies in Science Education, 46, 69-119. https://doi. org/10.1080/03057260903562433

Lewenstein, B. V. (2002). Editorial: A decade of Public Understanding. Public Understanding of Science, 11(1), 1-4. https://doi.org/10.1088/0963-6625/11/1/001 
Lima, G., \& Rocha, J. N. (2021). Interações Discursivas entre Educadores Museais e Estudantes: Um Estudo de Caso em um Museu de Ciências a partir das Contribuições de Bakhtin e do Círculo. Revista Brasileira De Pesquisa Em Educação Em Ciências, 21 1-33. https://doi.org/10.28976/1984-2686rbpec2021u3163

Marandino, M. (Org.) (2008). Educação em museus: a mediação em foco. FEUSP.

Marandino, M., Martins, L., Gruzman, C., Caffagni, C.W., Iszlaji, C., Campos, N, Mônaco, L., Salgado, M., Figueroa, A. M., \& Bigatto, M. (08-13 de novembro, 2009). A abordagem qualitativa nas pesquisas em educação em museus. VII Encontro Nacional de Pesquisa em Educação em Ciências (ENPEC), Florianópolis, Santa Catarina.

Marandino, M., Contier, D., Navas, A. M., Bizerra, A., \& Neves, A. L. (2016). Controvérsias em Museus de Ciências: reflexões e propostas para educadores. São Paulo: FE-USP. http:// www.geenf.fe.usp.br/v2/wp-content/uploads/2016/09/Controvérsias-em-Museus-deCiências.pdf

Miller, S. (2001). Public understanding of science at the crossroads. Public Understanding of Science, 10(1), 115-120. https://journals.sagepub.com/doi/10.3109/a036859

Miller, J. (2013). The Sources and Impact of Civic Scientific Literacy. In M. Bauer, R. Shulka, \& N. Allum, The Culture of Science: How the public relates to science across the globe (pp. 217-240). Routledge.

Miller, S. (2005). Os cientistas e a compreensão pública da ciência. In L. Massarani, J. Turney, \& I. Moreira, Terra Incógnita: a interface entre ciência e público (pp. 115-132). Casa da Ciência/UFRJ, Museu da Vida/Fiocruz, Vieira \& Lent.

Massarani, L., Reznik, G., Rocha, J. N., Falla, S., Rowe, S., Martins, A. D., \& Amorim, L. H. (2019a). A Experiência de Adolescentes Ao Visitar Um Museu De Ciência: Um Estudo No Museu Da Vida. Ensaio Pesquisa Em Educação Em Ciências (Belo Horizonte), 21, 1-25. https://doi.org/10.1590/1983-21172019210115

Massarani, L., Mucci Poenaru, L., Norberto Rocha J., Rowe, S. \& Falla, S. (2019b). Adolescents learning with exhibits and explainers: the case of Maloka, International Journal of Science Education, 9(3), 253-267. https://doi.org/10.1080/21548455.2019.16 46439

Massarani, L., Fazio, M. E., Norberto Rocha, J. Dávila, A., Espinosa, S. \& Bognanni, F. A. (2019c). La Interactividad En Los Museos de Ciencias, Pivote Entre Expectativas y Hechos Empíricos: El Caso Del Centro Interactivo de Ciencia y Tecnología Abremate (Argentina). Ciência \& Educação (Bauru), 25(2), 467-484. https://doi.org/10.1590/1516731320190020012

Massarani, L., Norberto Rocha, J., Mucci Poenaru, L., Bravo, M., Singer, S., \& Sánchez, E. (2020). O olhar dos adolescentes em uma visita ao Museo Interactivo de Economía (MIDE), México. Revista Iberoamericana de Ciencia, Tecnología y Sociedad - CTS, 15(44),173-195. 
Massarani, L., Castelfrancchi, Y., Fagundes, V., \& Moreira, I. C. (2021a). O que os jovens brasileiros pensam da ciência e da tecnologia: pesquisa realizada pelo Instituto Nacional de Ciência e Tecnologia em Comunicação Pública da Ciência e Tecnologia (INCT-CPCT). Casa de Oswaldo Cruz.

Massarani, L., Norberto Rocha, J., Scalfi, G., Gomes, Y., Cruz, W. S., \& Guedes, L. L. S. (2021b). Families Visit the Museum: A Study on Family Interactions and Conversations at the Museum of the Universe - Rio de Janeiro (Brazil). Frontiers in Education, 6, 1-12. https://doi.org/10.3389/feduc.2021.669467

Mota, H. (2013). Evolução biológica e religião: atitudes de jovens estudantes brasileiros (Tese de Doutorado, Universidade de São Paulo, São Paulo). Biblioteca Digital de Teses e Dissertações da USP. https://doi.org/10.11606/T.48.2013.tde-28012014-143821

Navas-Iannini, A. M, \& Pedretti, E. (2017). Preventing Youth Pregnancy: Dialogue and Deliberation in a Science Museum Exhibit. Canadian Journal of Science, Mathematics and Technology Education,17(4), 271-287.

Norberto Rocha, J. (2018). Museus e centros de ciências itinerantes: análise das exposições na perspectiva da Alfabetização Científica (Tese de Doutorado, Universidade de São Paulo, São Paulo). Biblioteca Digital de Teses e Dissertações da USP. https://doi. org/10.11606/T.48.2018.tde-03122018-122740

Norberto Rocha, J., \& Marandino, M. (2020). O papel e os desafios dos mediadores em quatro experiências de museus e centros de ciências itinerantes brasileiros. JCOM América Latina, 3(2). https://doi.org/10.22323/3.03020208

Norberto Rocha, J., Cunha, E., Massarani, L., Coelho, P., Dahmouche, M. S. (2021a). Uma exposição sobre a física dos esportes pelo olhar de adolescentes: um estudo de caso no Museu Ciência e Vida. Caderno Brasileiro De Ensino De Física, 38(1), 216-241. https://doi.org/10.5007/2175-7941.2021.e72189

Norberto Rocha, J., Velloso, R., Massarani, L., Magalhães, D. (2021b). Jovens e feiras de ciência: um estudo sobre a visita de adolescentes à feira de ciência, tecnologia e inovação do Estado do Rio de Janeiro. Alexandria, 14(1), 299-321. https://doi.org/10.5007/19825153.2021.e70742

Norberto Rocha, J., Massarani, L., Poenaru, L. M., Martins, A. L., Macias-Nestor, A. P. (no prelo). Um estudo sobre a leitura e a interação de adolescentes durante uma visita ao museu de ciências Universum - México. Anais Do Museu Paulista.

Oliveira, G. S., Bizzo, N., \& Pellegrini, G. (2017). Evolução Humana e Religião: Opiniões de Jovens Brasileiros e Italianos. Revista Brasileira De Pesquisa Em Educação Em Ciências, 17(1), 135-156. https://periodicos.ufmg.br/index.php/rbpec/article/view/4401

Oliveira, G. S., Bizzo, N., \& Pellegrini, G. (2016). Evolução biológica e os estudantes: um estudo comparativo Brasil e Itália. Ciência \& Educação (Bauru), 22(3), 689-705. https:// doi.org/10.1590/1516-731320160030009 
Rodari, P., \& Merzagora, M. (2007). Mediadores em museus e centros de ciência: Status, papéis e treinamento. Uma visão geral europeia. In L. Massarani (Org.). Diálogos \& Ciência: mediação em museus e centros de Ciência. Museu da Vida/Casa de Oswaldo Cruz/Fiocruz.

Schiele, B. (2008). Science museums and centers. In M. Bucchi, \& B. Trench, Handbook of Public Communication of Science and Technology. Routledge.

Soto Lombana, C., Angulo Delgado, F., \& Rickenmann, R. (2009). Ampliando la perspectiva escolar: Los Museos como espacio de formación. Enseñanza de las ciencias: revista de investigación y experiencias didácticas, (Extra), 3023-3027. https://www.raco. cat/index.php/Ensenanza/article/view/294598

Soto Lombana, C. A., Angulo-Delgado, F., Runge-Peña, A. K. \& Rendón-Uribe, M. A. (2013). Pensar la institución museística en términos de institución educativa y cultural, el caso del Museo de Antioquia. Revista Latinoamericana de Ciencias Sociales, Niñez y Juventud, 11(2), 819-833.

Sumartojo, S., \& Pink, S. (2017). Empathetic visuality: GoPros and the video trace. In E. Gomez Cruz, S. Sumartojo, \& S. Pink (Eds.), Refiguring Techniques In Digital Visual Research (pp. 39-50). Palgrave Macmillan. https://doi.org/10.1007/978-3-319-61222-5

Venturini, T. (2010). Diving in Magma: how to explore controversies with actornetwork theory. Public Understanding of Science, 19(3), 258-273. https://doi. org/10.1177/0963662509102694 
Jessica Norberto Rocha

Fundação Cecierj

Rio de Janeiro, Rio de Janeiro, Brasil jessicanorberto@yahoo.com.br

Luisa Massarani

Instituto Nacional de Comunicação Pública da Ciência e Tecnologia, Fundação Oswaldo Cruz

Rio de Janeiro, Rio de Janeiro, Brasil luisa.massarani6@gmail.com

Yurij Castelfranchi

Universidade Federal de Minas Gerais

Belo Horizonte, Minas Gerais, Brasil

yurijcastelfranchi@gmail.com

Juliane dos Santos Amorim

Universidade Federal de Minas Gerais

Belo Horizonte, Minas Gerais, Brasil

juliane_jsa@hotmail.com

Editora Responsável

Marta Máximo

Manifestação de Atenção às Boas Práticas Científicas e de Isenção de Interesse

Os autores declaram ter cuidado de aspectos éticos ao longo do desenvolvimento da pesquisa e não ter qualquer interesse concorrente ou relações pessoais que possam ter influenciado o trabalho relatado no texto. 